\title{
Climate Change Impacts on Water Resources of Nepal with Reference to the Glaciers in the Langtang Himalayas
}

\author{
Narayan Pras ad Chaulagain \\ Alternative Energy Promotion Centre, Kathmandu Nepal \\ Email: narayanchaulagain@gmail.com
}

\begin{abstract}
The impacts of climate change on water resources of Nepal with reference to snow and glacier were assessed. Empirical glacier mass model was applied to all the glaciers upstream of the Kyangjing hydrological station in the Langtang Valley in the Nepal Himalayas in order to assess their sensitivity to the increases in temperature. The analysis has revealed that the glaciers in the study area of the Nepal Himalayas are shrinking rapidly and may disappear within less than two centuries, if the current glacier melting rate continues. Most of the glaciers will disappear within 3-4 decades; there may be only 24\% of the present glacier-ice reserve left in the study basin of the Nepal Himalayas by $2100 \mathrm{AD}$ even without any further warming which may result in serious adverse impacts on the water resources of Nepal.
\end{abstract}

Key Words: Climate Change, Water Resources, Nepal Himalayas, Glaciers

\section{BACKGROUND}

Nepal is rich in water resources. There are more than 6000 rivers flowing from the Himalayan Mountains to the hills and plains. Most of these rivers are glacier-fed and provide sustained flows during dry seasons to fulfil the water requirements of downstream. Accelerated melting of glaciers during the last half century has caused creation of many new glacier lakes and expansion of existing ones in the Nepal Himalayas (Mool et al., 2001). There have been more than 13 reported cases of glacier lake outburst flood events in the Nepal Himalayas since 1964 causing substantial damage to people's lives, livestock, land, environment and infrastructure (ibid). Accelerated retreat of glaciers with increased intensity of monsoon precipitation observed during recent years has most probably contributed to increased frequency of such floods. The major rivers of Nepal are fed by melt-water from over three thousand glaciers scattered throughout the Nepal Himalayas. These rivers feed irrigation systems, agro-processing mills and hydroelectric plants and supply drinking water for villages for thousands of kilometres downstream. Climate change will contribute to increased variability of river runoff due to changes in timing and intensity of precipitation as well as melting of glaciers (Agrawala et al., 2003). Runoff will initially increase as glaciers melt, then decrease later as the glaciers disappear (ibid).

Climate change may alter rainfall and snowfall patterns. The incidence of extreme weather events such as droughts, storms, floods and avalanches is expected to increase. This can lead to loss of lives and severely reduce agricultural production. Traditional wisdom and knowledge to cope with such natural hazards that once ensured food security may no longer prove effective. Climateinduced natural hazards have very serious human implications because they affect the livelihood security of the majority of the population. About $29 \%$ of the total annual deaths of people and $43 \%$ 
of the total loss of properties from all different disasters in Nepal are caused by water-induced disasters like floods, landslides and avalanches (Khanal, 2005).

Higher temperatures will increase the ratio of rain to snow; accelerate the rate of snow- and glaciermelt; and shorten the overall snowfall season. Since the end of the Little Ice Age, the temperatures have been generally increasing and the majority of the world's glaciers are retreating (IPCC, 2001). Increasing temperature shifts the permanent snowline upward. This could cause a significant reduction of water storage in the mountains, which is likely to pose serious problems of water availability to many people living downstream.

The Himalayan glaciers are melting faster in recent years than before (IPCC, 2007). The Himalayan Rivers are expected to be very vulnerable to climate change because snow and glacier melt-water make a substantial contribution to their runoff. However, the degree of sensitivity may vary among the river systems. The magnitudes of snowmelt floods are determined by the volume of snow, the rate at which the snow melts and the amount of rain that falls during the melt period (IPCC, 1996). Because the melting season in the Himalayas coincides with the summer monsoon season, any intensification of monsoon or accelerated melting would contribute to increased summer runoff that ultimately would result in increased risk of flood disasters (IPCC, 2001).

Stream-flow in most of the rivers in Nepal is at a minimum in early spring because flows recede rapidly after the summer rains. This period of minimum flow is problematic for the run-of-river hydroelectric facilities (Kattelmann, 1993). Snowfed rivers provide sustained flow even during this critical period through the melt-water contribution. Agarawala et al. (2003) have also reported that a possible decrease in river runoff, as indicated by most projections, would reduce not only the electricity generation of existing plants but also the total hydropower potential of Nepal. In addition, there might be significant declines in the dry season flows and an increasing trend in the number of flooding days because of climate change, which is critical for hydropower generation (Agrawala $e t$ al., 2003). The flows of glacier-fed rivers first increase due to warming, as more water is released by the melting of snow and glaciers. As the glaciers get smaller and the volume of melt-water reduces, the dry season flows will no longer be supported by melt-water and eventually will decline (Shrestha, 2005). Therefore, the reduced dry season flow caused by a temperature rise could result in reduced hydropower potential.

Climate change will lead to increased climatic variability, which would lead to increased frequency and magnitude of weather-related extreme events (Becker and Bugmann, 1997). An extreme climatic event will result in higher losses of life in a developing country than in a developed country because of a different adaptive capacity (IPCC, 2001). An extreme climatic event combined with the socio-political characteristics of the region can become a social catastrophe in the developing countries (ibid). In Nepal, the normal daily life of a large section of the population is already not so different from the living conditions of those hit by a disaster (Dixit, 2003). Climate change brings additional threats to the livelihoods of these people (McGuigan et al, 2002).

\section{STUDY AREA}

The Langtang Khola Basin upstream of the hydrological station of Kyangjing with a basin area of 340 square kilometres with 24 glaciers within it in the central Nepal was taken as study site in order to quantify the sensitivities of glaciers to temperature rise.

\section{METHODOLOGY}

An empirical glacier mass balance model originally developed by Y. Ageta in 1983 using the observational data in 1978 and 1979 to calculate the mass balance of Glacier AX010 in the Nepal 
Himalayas (Kadota and Ageta, 1992) was used to assess the sensitivity of the glaciers in the study basin. The information on glaciers including their area, position and ice reserve was taken from the inventory published by the International Centre for Integrated Mountain Development (Mool et al., 2001). Topographic maps published by the Department of Survey of the study area were also used to identify the glaciers within the basin area. The hydrological and meteorological observation data for the period of 1988-2000 collected at Langtang (Kyangjing) by the Department of Hydrology and Meteorology of Nepal were also used.

The accumulation and ablation of the glaciers within the Langtang valley were calculated for each month and for every $100 \mathrm{~m}$ altitude level from 3900 to 7218 masl. Seko (1987) has suggested that precipitation in Langtang area increases with altitudes and that precipitation above 5000 masl is 1.3 times more than that in Kyangjing. However, due to lack of other studies to support this and also for the sake of simplicity, the precipitation for the whole study basin was assumed to be uniform over the whole study basin as recorded by the meteorological station at Langtang (Kyangjing) located at 3920 masl. As far as temperature data were concerned, the adiabatic lapse rate (i.e. the rate of temperature change with altitude) was taken as $-0.6^{\circ} \mathrm{C}$ per $100 \mathrm{~m}$ of altitude. The lapse rate was assumed to be the same for all altitude levels and for all months. The total accumulation, ablation and glacier mass balance for each $100 \mathrm{~m}$ altitude level were calculated by summing up all monthly values. The specific glacier mass balance was calculated by summing up of that of all elevation zones from $3800 \mathrm{~m}$ above sea level to $7200 \mathrm{~m}$ above sea level and divided by the total glacier area. The relationship between the temperature, precipitation and glacier mass balance is defined by the following equations (Ageta and Kadota, 1992, Naito et al., 2000; Naito et al., 2001):

$\mathrm{c}=\mathrm{P} \quad$ if $\mathrm{T}<-0.6$

$\mathrm{c}=\mathrm{P}(0.85-0.24 \mathrm{~T})$ if $-0.6 \leq \mathrm{T} \leq 3.5$

$$
\begin{array}{rl}
\mathrm{c} & =0 \quad \text { if } \mathrm{T}>3.5 \\
\mathrm{a} & =0 \quad \text { if } \mathrm{T}<-3.0 \\
\mathrm{a} & =-0.30(\mathrm{~T}+3.0)^{3.2} \text { if }-3.0 \leq \mathrm{T} \leq 2.0 \\
\mathrm{a}=-30^{*} & 0.9 \mathrm{~T} \quad \text { if } \mathrm{T}>2.0 \\
\mathrm{~b}=\mathrm{c}+\mathrm{a} & \\
\text { where, } & \\
\mathrm{c} & =\text { accumulation, cm/month } \\
\mathrm{a} & =\text { ablation, cm/month } \\
\mathrm{b} & =\text { mass balance, cm/month } \\
\mathrm{P} & =\text { average monthly precipitation, } \mathrm{cm} \\
\mathrm{T} & =\text { average monthly temperature, }{ }^{\circ} \mathrm{C}
\end{array}
$$

The calculated accumulation, ablation and mass balance values of glaciers in Langtang valley were tested for their validity by calculating total water balance at the Kyangjing hydrological station. The observed average annual runoff $\left(\mathrm{Q}_{\mathrm{o}}\right)$ at Kyangiing was compared with the calculated average annual runoff $\left(Q_{c}\right)$. The following relation was used for calculating the average annual runoff:

$\mathrm{Q}_{\mathrm{c}}=\mathrm{P}+\mathrm{M}_{\mathrm{w}}-\mathrm{E}$

where,

$Q_{c}=$ average calculated annual runoff, $\mathrm{m}^{3}$

$\mathrm{P}=$ average annual precipitation, $\mathrm{m}^{3}$

$\mathrm{M}_{\mathrm{w}}=$ average annual melt water, $\mathrm{m}^{3}$

$\mathrm{E}=$ average annual evapo-transpiration calculated using FAO Penman-Monteith Method, $\mathrm{m}^{3}$

The infiltration into the ground was ignored for the annual water balance calculation. Average annual melt water was calculated as the net glacier mass balance within the study basin. The observed average annual runoff $\left(\mathrm{Q}_{\mathrm{o}}\right)$ at Kyangjing for the period of 1988-2000 was 218 million cubic metres whereas the calculated average annual runoff $\left(Q_{c}\right)$ for the same area was 217.4 million cubic metres. Further, the specific mass balance was obtained by:

$\mathrm{b}=\mathrm{B} / \mathrm{A}$

where,

$\mathrm{b}=$ specific mass balance, metres of water equivalent ( $\mathrm{m}$ w.e.),

$\mathrm{B}=$ total glacier mass balance, $\mathrm{m}^{3}$

$\mathrm{A}=$ total glacier surface area, $\mathrm{m}^{2}$ 
In order to determine the sensitivity of glacier extent to temperature rise, the specific glacier mass balance rates were calculated with different temperature change scenarios. Ice reserve of any particular glacier in any particular year was calculated as:

$\mathrm{IR}_{\mathrm{n}+1}=\mathrm{IR}_{\mathrm{n}}+\mathrm{b} * \mathrm{~A}$

where,

$\mathrm{IR}_{\mathrm{n}+1}=$ ice reserve in the particular glacier in $\mathrm{n}+1^{\text {th }}$ year, $\mathrm{m}^{3}$

$\mathrm{IR}_{\mathrm{n}}=$ ice reservein the particular glacier in $\mathrm{n}^{\text {th }}$ year, $\mathrm{m}^{3}$

$\mathrm{b}=$ specific glacier mass balance, m.w.e/year

$\mathrm{A}=$ surface area of that particular glacier, $\mathrm{m}^{2}$

The estimated life of any glacier was calculated by:

$\mathrm{N}=\mathrm{IR} / \mathrm{b}$

where,

$\mathrm{N}=$ estimated life of ice reserve in the particular glaciers in years

$\mathrm{IR}=$ ice reserve in the particular glacier in $2001, \mathrm{~m}^{3}$

$\mathrm{b}=$ specific glacier mass balance, m.w.e/year

A projected time series of average annual ice reserve in any particular glacier was developed. Any glacier was considered as disappeared, when $\mathrm{IR}_{\mathrm{n}+1}<0$, i.e. when there was no more ice-reserve left in the glacier. Similarly, sensitivity analyses of glacier ice reserve, glacier number and glacier areas to warming were carried out for different rates of temperature rise from $0.03^{\circ} \mathrm{C} / \mathrm{yr}$ to $+0.15^{\circ} \mathrm{C} / \mathrm{yr}$.

\section{FINDINGS AND DISCUSSION}

\subsection{GENERAL FINDINGS}

The highest and lowest points within the study basin were at 7232 and 3800 metres above sea level (masl) respectively. The glaciers were distributed from the lowest point of 4130 masl to the highest point of 7218 masl. The smallest glacier was 0.01 $\mathrm{km}^{2}$ whereas the largest one was $67.93 \mathrm{~km}^{2}$. The thickness of the glaciers also varied from $2.1 \mathrm{~m}$ to $177.3 \mathrm{~m}$. Out of the 24 glaciers, the largest one alone had an ice reserve of $12.04 \mathrm{~km}^{3}$ (i.e. $63 \%$ of the total ice reserve in the basin), and the second and the third largest ones had ice reserves of 3.32 $\mathrm{km}^{3}$ and $1.84 \mathrm{~km}^{3}$ respectively. The remaining 21 glaciers had altogether only $10 \%$ of the whole ice reserve in the basin indicating that the majority of the glaciers were very small. The accumulation and ablation largely varied with altitudes. The lower altitudes were dominated by ablation whereas the upper ones by accumulation (see Figure 1). The equilibrium line altitude, the altitude at which the accumulation and ablation of the glacier is equal, was found at 5367 masl.

The total volume of the glacier mass balance over the whole glaciers was obtained by summing up all glacier mass balances at each altitude level. The total glacier mass balance in terms of volume of water equivalent (w.e.) was further divided by the glacier area in order to get a specific mass balance The calculated monthly specific mass balance of the glaciers shows that there was a substantial negative glacier mass balance during the study period of 1988-2000 in the study area. There was a wide variation of glacier mass balance among the months (see Figure 2). The summer months (June-September) had substantial glacier ablation despite some accumulation.

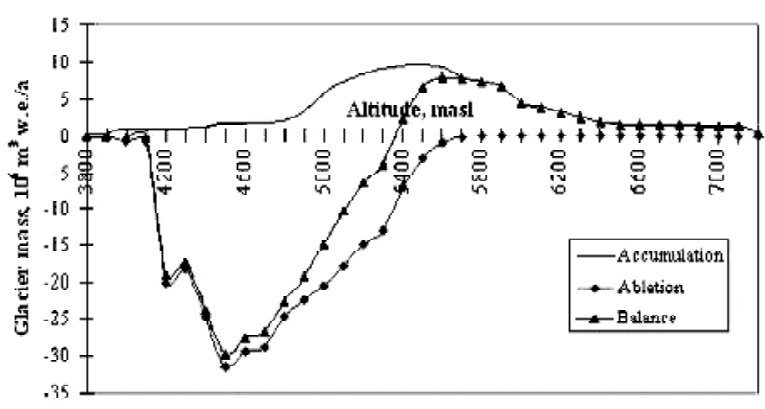

Figure 1: Average Glacier Mass Balance in Different Altitude

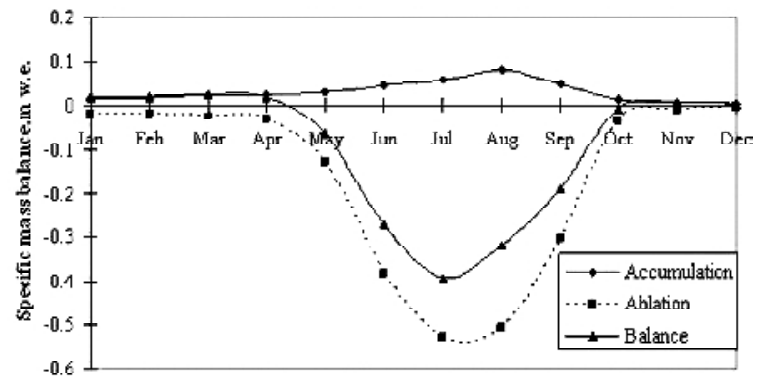

Figure 2 : Monthly Glacier Mass Balance at Langtang 


\subsection{SENSITIVITY ANALYSIS OF GLACIER MASS BALANCE TO TEMPERATURE RISE}

As the precipitation data during the past did not show any significant trends, a sensitivity analysis of glacier mass balance and glacier-contributed runoff was carried out only for the temperature change scenarios from $T_{+1}$ to $T_{+5}$ (i.e. temperature rise from $1^{\circ} \mathrm{C}$ to $5^{\circ} \mathrm{C}$ ). Then, the calculated values were compared with the $\mathrm{T}_{0}$-scenario (no temperature change). The equilibrium line altitude (ELA) would move upward to 6142 masl with a temperature rise of $5^{\circ} \mathrm{C}$ (i.e. at $\mathrm{T}_{+5}$-scenario), from the present ELA at 5367 masl (see Figure 3).

A temperature increase will not only impact the annual glacier mass balance, but will also change the precipitation pattern. Even without any change in total annual precipitation, more precipitation will occur in a liquid form (i.e. rainfall) instead of a solid form (i.e. snowfall) with warmer temperatures. Rainfall, unlike snowfall, will not be stored, but will immediately be drained out from the basin resulting in more floods downstream during the monsoon. The impact of a temperature rise could easily be visible in the sensitivity analysis through snow-to-rain ratio, glacier mass balance rate or life of glacier ice reserve. For example, the snow-to-rain ratio would decrease from 1.6 to 0.5 , the life of ice reserves would decrease from 110 to 25 years and the glacier mass balance would decrease from -1.114 to -4.850 m.w.e. $\mathrm{yr}^{-1}$ with a warming of $4^{\circ} \mathrm{C}$. Likewise, the analysis has shown that even without any changes in the precipitation amount, a warming of $5^{\circ} \mathrm{C}$ would cause a decrease in snowfall of $55.6 \%$ and an increase in rainfall of $89.2 \%$ simultaneously (see Table 1 ).

A further calculation was done in order to quantify a glacier mass balance rate for a particular rate of temperature increase instead of the total amount of warming. The regression analysis between an increase in temperature and a glacier mass balance revealed the empirical relation given in Equation $12\left(\mathrm{p}<0.001 ; \mathrm{R}^{2}=1.0\right)$

$\Delta \mathrm{B}=-0.6087^{*} \Delta \mathrm{T}^{1.3117}$

where,

$\Delta \mathrm{B}=$ change in glacier mass balance in m.w.e. $\mathrm{yr}^{-1}$ $\Delta \mathrm{T}=$ change in temperature in ${ }^{\circ} \mathrm{C}$

Using the relation, glacier mass balance rates for the next 20 decades from 2001 were calculated (see Table 2). The mass balance rates were calculated using the output values from Table 1 for different scenarios of temperature rise and then converted to the rate of warming using the Equation 12. For example, the negative glacier mass balance rate for the $\mathrm{T}_{0}$-scenario was taken as the same as the average calculated value for the period of 19882000. The negative glacier mass balance rates for

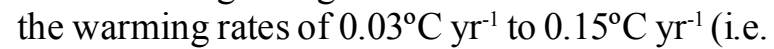
$\mathrm{T}+{ }_{0.03}, \mathrm{~T}+{ }_{0.06}, \ldots, \mathrm{T}_{+0.15}$-scenarios) for every decade were calculated by:

$\mathrm{B}_{\mathrm{T}, \mathrm{n}}=\mathrm{B}_{\mathrm{T} 0, \mathrm{n}}+\Delta \mathrm{B}_{\mathrm{x}, \mathrm{n}}$

where,

$\mathrm{B}_{\mathrm{T} x, \mathrm{n}}=$ glacier mass balance rate for $\mathrm{n}$-decade with a warming rate of $x$ (Here, $x=0,0.03,0.06,0.09$, $\left.0.12,0.15^{\circ} \mathrm{C} / \mathrm{yr} ; \mathrm{n}=0,1,2, \ldots, 20\right)$,

$\mathrm{B}_{\mathrm{T} 0, \mathrm{n}}=$ glacier mass balance rate for $\mathrm{n}$-decade without a further warming

$\Delta \mathrm{B}_{\mathrm{x}, \mathrm{n}}=$ change in glacier mass balance rate for $\mathrm{n}$ decade with a warming rate of $\mathrm{x}$

Table 1: Summary of Sensitivity Analysis of Glaciers at Langtang (1988-2000)

\begin{tabular}{|l|l|r|r|r|r|r|r|}
\hline \multirow{2}{*}{ Parameters } & \multirow{2}{*}{ Unit } & \multicolumn{6}{c|}{ Temperature Change Scenarios } \\
\cline { 3 - 7 } & & \multicolumn{1}{c|}{$T_{0}$} & \multicolumn{1}{c|}{$T_{+1}$} & \multicolumn{1}{c|}{$T_{+2}$} & \multicolumn{1}{c|}{$T_{+3}$} & \multicolumn{1}{c|}{$T_{+4}$} & \multicolumn{1}{c|}{$T_{+5}$} \\
\hline Precipitation & $10^{6} \mathrm{~m}^{3} \mathrm{yr}^{-1}$ & 199.0 & 199.0 & 199.0 & 199.0 & 199.0 & 199.0 \\
\hline Snowfall & $10^{6} \mathrm{~m}^{3} \mathrm{yr}^{-1}$ & 122.6 & 108.6 & 93.5 & 79.0 & 66.6 & 54.4 \\
\hline Rainfall & $10^{6} \mathrm{~m}^{3} \mathrm{yr}^{-1}$ & 76.4 & 90.4 & 105.5 & 120.0 & 132.4 & 144.6 \\
\hline Snow-to-rain ratio & & 1.60 & 1.20 & 0.89 & 0.66 & 0.50 & 0.38 \\
\hline Evaporation & $10^{6} \mathrm{~m}^{3} \mathrm{yr}^{-1}$ & 138.0 & 142.8 & 147.7 & 152.6 & 157.6 & 162.7 \\
\hline Ablation & $10^{6} \mathrm{~m}^{3} \mathrm{yr}^{-1}$ & 279.0 & 351.6 & 463.6 & 596.9 & 750.8 & 925.7 \\
\hline Accumulation & $10^{6} \mathrm{~m}^{3} \mathrm{yr}^{-1}$ & 122.6 & 108.6 & 93.5 & 79.0 & 66.6 & 54.4 \\
\hline Total mass balance & $10^{6} \mathrm{~m}^{3} \mathrm{yr}^{-1}$ & -156.8 & -242.8 & -369.5 & -516.7 & -683.0 & -870.5 \\
\hline Specific mass balance & $\mathrm{m} \cdot \mathrm{w} \cdot \mathrm{yr}^{-1}$ & -1.114 & -1.724 & -2.623 & -3.668 & -4.850 & -6.181 \\
\hline Life of ice reserve & year & 110 & 71 & 47 & 33 & 25 & 20
\end{tabular}


Table 2: Glacier Mass Balance Rates with Different Temperature Change Scenarios

\begin{tabular}{|c|c|c|c|c|c|c|}
\hline \multirow[t]{3}{*}{ Decade } & \multicolumn{6}{|c|}{ Specific Glacier Mass Balance, m.w.e./year } \\
\hline & \multicolumn{6}{|c|}{$\Delta \mathrm{T}$} \\
\hline & $0^{\circ} \mathrm{C} / \mathrm{yr}$ & $0.03^{\circ} \mathrm{C} / \mathrm{yr}$ & $0.06^{\circ} \mathrm{C} / \mathrm{yr}$ & $0.09^{\circ} \mathrm{C} / \mathrm{yr}$ & $0.12^{\circ} \mathrm{C} / \mathrm{yr}$ & $0.15^{\circ} \mathrm{C} / \mathrm{yr}$ \\
\hline 0 & -1.114 & -1.114 & -1.114 & -1.114 & -1.114 & -1.114 \\
\hline 1 & -1.114 & -1.239 & -1.425 & -1.644 & -1.887 & -2.150 \\
\hline 2 & -1.114 & -1.425 & -1.887 & -2.430 & -3.033 & -3.685 \\
\hline 3 & -1.114 & -1.644 & -2.430 & -3.353 & -4.380 & -5.491 \\
\hline 4 & -1.114 & -1.887 & -3.033 & -4.380 & -5.878 & -7.498 \\
\hline 5 & -1.114 & -2.150 & -3.685 & -5.491 & -7.498 & -9.669 \\
\hline 6 & -1.114 & -2.430 & -4.380 & -6.674 & -9.223 & -11.980 \\
\hline 7 & -1.114 & -2.724 & -5.112 & -7.920 & -11.040 & -14.415 \\
\hline 8 & -1.114 & -3.033 & -5.878 & -9.223 & -12.940 & -16.961 \\
\hline 9 & -1.114 & -3.353 & -6.674 & -10.577 & -14.916 & -19.609 \\
\hline 10 & -1.114 & -3.685 & -7.498 & -11.980 & -16.961 & -22.350 \\
\hline 11 & -1.114 & -4.028 & -8.348 & -13.427 & -19.072 & -25.178 \\
\hline 12 & -1.114 & -4.380 & -9.223 & -14.916 & -21.243 & -28.087 \\
\hline 13 & -1.114 & -4.742 & -10.120 & -16.444 & -23.471 & -31.074 \\
\hline 14 & -1.114 & -5.112 & -11.040 & -18.009 & -25.754 & -34.132 \\
\hline 15 & -1.114 & -5.491 & -11.980 & -19.609 & -28.087 & -37.260 \\
\hline 16 & -1.114 & -5.878 & -12.940 & -21.243 & -30.470 & -40.453 \\
\hline 17 & -1.114 & -6.272 & -13.919 & -22.909 & -32.900 & -43.709 \\
\hline 18 & -1.114 & -6.674 & -14.916 & -24.606 & -35.375 & -47.025 \\
\hline 19 & -1.114 & -7.082 & -15.930 & -26.332 & -37.893 & -50.400 \\
\hline 20 & -1.114 & -7.498 & -16.961 & -28.087 & -40.453 & -53.830 \\
\hline
\end{tabular}

Then, all values of the specific glacier mass balance for every temperature rise scenario and for each decade were calculated (see Table 2). The decades were counted from 2001, e.g. decade-0 means 2000 , decade- 1 means 2010 , decade- 3 means $2030 \ldots$, and so on. The glacier-ice reserve of each glacier was calculated by:

$\mathrm{V}_{\mathrm{x}, \mathrm{n}}=\mathrm{V}_{\mathrm{x}, \mathrm{n}-\mathrm{1}}+\mathrm{B}_{\mathrm{x}, \mathrm{n}} * \mathrm{~A}_{\mathrm{n}}$

where,

$\mathrm{V}_{\mathrm{x}, \mathrm{n}} \quad=$ volume of glacier-ice reserve in n-year for a warming rate of $\mathrm{x}\left[\mathrm{m}^{3}\right]$,

$\mathrm{V}_{\mathrm{x}, \mathrm{n}-1}=$ volume of glacier-ice reserve in $\mathrm{n}-1$ year for a warming rate of $\mathrm{x}\left[\mathrm{m}^{3}\right]$,

$\mathrm{B}_{\mathrm{x}, \mathrm{n}} \quad=$ specific glacier mass balance in n-year for a warming rate of $x$ [m w.e./yr] and

$\mathrm{A}_{\mathrm{n}} \quad=$ surface area of the particular glacier in $\mathrm{n}$-year $\left[\mathrm{m}^{2}\right]$

Journal of Hydrology and Meteorology, Vol.6, No. 1
The total glacier-ice reserve in the study basin for a particular year was obtained by summing up the ice reserve of all existing glaciers for the same year (see Figure 4). The analysis shows that the glacier-ice reserve will substantially be decreasing and the rate of reduction of glacier ice-reserve will increase with the rate of warming.

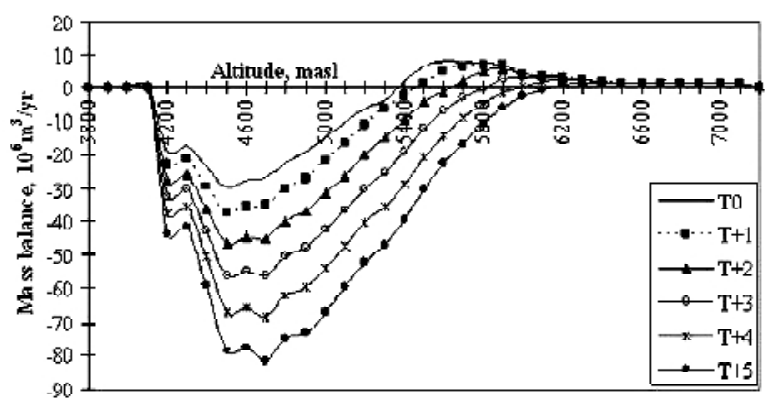

Figure 3: Sensitivity of Glacier Mass Balance in Different Altitudes 


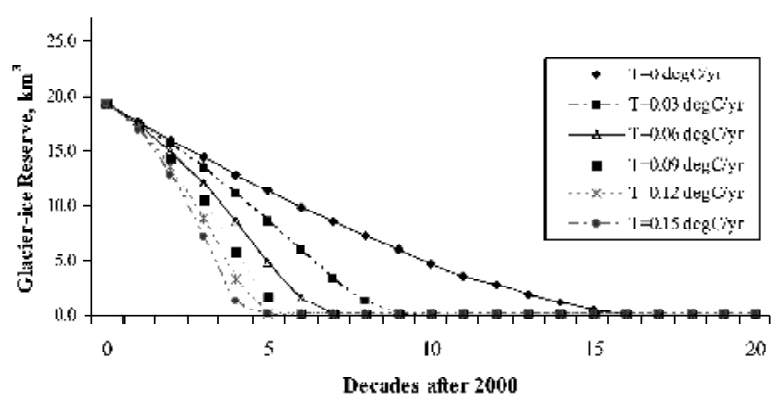

Figure 4: Sensivity of Glacier-ice Reserve to Warming

The analysis has revealed that even without any further warming, there will be only $4.7 \mathrm{~km}^{3}$ of glacier-ice reserve left by the year 2100 , which is only $24.6 \%$ of the present glacier-ice reserve of $19.1 \mathrm{~km}^{3}$. Likewise, there will be no glacier-ice reserve left by the year 2160, if the current rate of melting continues even without further warming (see Figure 4). The maximum temperature in the Nepal Himalayas is increasing by at least $0.06^{\circ} \mathrm{C}$ per year (Shrestha et. al, 1999), which would further accelerate the glacier melt. If this rate of warming (i.e. an increase of mean annual temperature by $0.06^{\circ} \mathrm{C}$ per year) continues, all the glaciers in the study basin will disappear by the year 2060 .

\section{CONCLUSION}

Increasing temperatures would accelerate the glacier melt in the study area, which indicates possible adverse impacts on water resources of Nepal. Increasing temperature will accelerate the glacier-melt and increase the proportion of liquid precipitation, which may create favourable conditions for the formation and growth of glaciers lakes in the high mountain valleys of Nepal. Being supported by loose moraine dams, any increase in water levels in these lakes may result in the increased likelihoods of glacial lake outburst floods. Besides, increased temperatures may result in decreased seasonal storage of water from monsoon to non-monsoon seasons because a large portion of liquid precipitation (i.e. rainwater) immediately flows out from the area of its occurrence unless it is artificially stored.

Journal of Hydrology and Meteorology, Vol. 6, No. 1

\section{REFERENCES}

Ageta, Y. and T. Kadota, 1992. Predictions of changes of glacier mass balance in the Nepal Himalaya and Tibetan Plateau: a case study of air temperature increase for three glaciers. In: Annals of Glaciology 16. International Glaciological Society, pp.89-94

Agrawala, S., V. Raksakulthai, M. Aalst, P. Larsen, J. Smith and J. Reynolds, 2003. Development and climate change in Nepal: Focus on water resources and hydropower. Paris: Organization for Economic Cooperation and Development.

Becker, A. and H. Bugmann, 1997. Predicting global change impacts on mountain hydrology and ecology: integrated catchment hydrology/altitudinal gradient studies. IGBP Report 43, International Geosphere-Biosphere Programme, Stockholm, 61 pp.

Dixit, A., 2003. Floods and vulnerability. In: Natural Hazards 28, [Mirza, M.N.Q, A.Dixit and Ainun Nishat (eds.)], Kluwer Academic Publishers, Dordrecht, pp.155-179

IPCC, 1996. Climate Change 1995-Impacts, adaptations and mitigation of climate change: scientific-technical analyses. Contribution of Working Group II to the Second Assessment Report of the Intergovernmental Panel on Climate Change [Watson, R.T., M.C. Zinyowera, R.H. Moss and D.J. Dokken (eds.)], Cambridge University Press, 880 pp.

IPCC, 2001. Climate Change 2001: Impacts, Adaptation, and Vulnerability. Contribution of WG II to TAR of the Intergovernmental Panel on Climate Change [McCarthy, M.C., O.F. Canziani, N.A. Leary, D.J. Dokken and K.S. White (eds.)] Cambridge, 1031 pp.

SOHAM-Nepal 
IPCC, 2007. Climate Change 2007: Climate Change Impacts, Adaptation and Vulnerability. Summary for Policy Makers. Working Group II Contribution to the Intergovernmental Panel for Climate Change Fourth Assessment Report. Cambridge University Press.

Kadota, Tand Y.Ageta, 1992. On the relation between climate and retreat of Glacier AX010 in the Nepal Himalaya from 1978 to 1989. In: Bulletin of Glacier Research 10. Data Centre for Glacier research. Japanese Society of Snow and Ice, pp. 1-10.

Kattelmann, R., 1993. Role of snowmelt in generating stream-flow during spring in east Nepal. In: Snow and glacier hydrology (Proceedings of the Kathmandu symposium, November 1992), IAHS Publ. No. 218: pp.103-111

Khanal, N.R., 2005. Water induced disasters: Case studies from the Nepal Himalayas. In: Landschaftsökologie und Umweltforschung 48 (Proceedings of International Conference on Hydrology of Mountain Environments, Berchtesgaden, Germany, 27 Sept-1 Oct 200448 [Herrmann, A. (ed.)], Braunschweig, pp. 179-188.

McGuigan, C., R. Reynolds and D. Wiedmar, 2002. Poverty and climate change: assessing impacts in developing countries and the initiatives of the international community. London School of Economics, London, $39 \mathrm{pp}$.

Mool, P.K., S.R. Bajracharya and S.P. Joshi, 2001. Inventory of Glaciers, Glacial Lakes and Glacial Lake Outburst Floods Monitoring and Early Warning Systems in the Hindu Kush-Himalayan Region, Nepal. ICIMOD, Kathmandu, $363 \mathrm{pp}$.

Journal of Hydrology and Meteorology, Vol. 6, No. 1
Naito, N., M. Nakawo, T. Kadota and C. F. Raymond, 2000. Numerical simulation of recent shrinkage of Khumbu Glacier, Nepal Himalayas. In: Debris-Covered Glaciers (Proceedings of a workshop held at Seatle, Washington, September 2000), IAHS Publi. No. 264, pp.245-254

Naito, N., Y.Ageta, M. Nakawo, E. D. Waddington, C. F. Raymond and H. Conny, 2001. Response sensitivities of a summeraccumulation type glacier to climate change indicated with a glacier fluctuation model. In: Bulletin of Glaciological Research 18, Japanese Society of Snow and Ice, pp. 315-322

Seko, 1987; Seasonal variation of altitudinal dependence of precipitation in Langtang Valley, Nepal Himalayas. In: Bulletin of glacier research 5, Data center for glacier research, Japanese society for snow and ice, pp.41-47

Shrestha, A.B., C.P.Wake, J.E Dibb and P.A. Mayewski, 1999. Maximum Temperature Trends in the Himalaya and Its Vicinity: An Analysis Based on Temperature Records from Nepal for the Period 197194. In: Journal of Climate Vol. 12, American Meteorological Society, pp. 2775-2786

Shrestha, K.L., 2005. Global change impact assessment for Himalayan mountain regions for environmental management and sustainable development. In: Global Environmental Research, 9(1): pp.69-81 